\title{
Occupational exposure to carcinogens: Benzene, pesticides and fibers (Review)
}

\author{
LUCA FALZONE $^{1}$, ANDREA MARCONI ${ }^{2}$, CARLA LORETO $^{3}$, \\ SABRINA FRANCO $^{4}$, DEMETRIOS A. SPANDIDOS ${ }^{5}$ and MASSIMO LIBRA ${ }^{1}$
}

${ }^{1}$ Department of Biomedical and Biotechnological Sciences, Section of General and Clinical Pathology and Oncology,
University of Catania; ${ }^{2}$ Section of Occupational Medicine, Department of Clinical and Experimental Medicine,
University of Catania; ${ }^{3}$ Department of Biomedical and Biotechnological Sciences, Human Anatomy
and Histology Section, School of Medicine, University of Catania; ${ }^{4}$ Department of Medical, Surgical
and Advanced Technology Sciences 'G.F. Ingrassia', University of Catania, I-95124 Catania, Italy;
${ }^{5}$ Laboratory of Clinical Virology, Medical School, University of Crete, Heraklion 71003, Greece

Received July 25, 2016; Accepted September 20, 2016

DOI: $10.3892 / \mathrm{mmr} .2016 .5791$

\begin{abstract}
It is well known that the occupational exposure to contaminants and carcinogens leads to the development of cancer in exposed workers. In the 18th century, Percivall Pott was the first to hypothesize that chronic exposure to dust in the London chimney sweeps was associated with an increased risk of developing cancer. Subsequently a growing body of evidence indicated that other physical factors were also responsible for oncogenic mutations. Over the past decades, many carcinogens have been found in the occupational environment and their presence is often associated with an increased incidence of cancer. Occupational exposure involves several factors and the association between carcinogens, occupational exposure and cancer is still unclear. Only a fraction of factors is recognized as occupational carcinogens and for each factor, there is an increased risk of cancer development associated with a specific work activity. According to the International Agency for Research on Cancer (IARC), the majority of carcinogens are classified as 'probable' and 'possible' human carcinogens, while, direct evidence of carcinogenicity is provided in epidemiological and experimental studies. In the present review, exposures to benzene, pesticides and mineral fibers are discussed as the most important cancer risk factors during work activities.
\end{abstract}

Correspondence to: Dr Massimo Libra, Department of Biomedical and Biotechnological Sciences, Section of General and Clinical Pathology and Oncology, University of Catania, 83 Via Androne, I-95124 Catania, Italy

E-mail:mlibra@unict.it

Key words: benzene, pesticides, fibers, asbestos, cancer risk, occupational exposure

\author{
Contents \\ 1. Introduction \\ 2. Benzene \\ 3. Pesticides \\ 4. Fibers \\ 5. Conclusions
}

\section{Introduction}

Occupational cancer remains a major concern due to of worker's exposure to carcinogens. Percivall Pott was the first to describe occupational cancer in the 18th century, caused by dust in chimney sweeps (1). In 1926, Muller discovered a clear association between X-rays and lethal mutations (2). Apart from such physical factors, up to the 1970 s, the majority of recognized human carcinogenic factors were observed primarily in the occupational environment (3).

The association between occupational exposure and cancer has not yet been fully determined. Often, occupational exposure involves a combination of factors; only a fraction of factors is recognized as occupational carcinogens. However, in several cases, there is a significant indication of an increased risk of cancer development associated with a specific work activity (4).

Considerations and evaluations, reported by the International Agency for Research on Cancer (IARC), reveal that the majority of carcinogens are classified as 'probable' and 'possible' human carcinogens (5). Direct evidence of carcinogenicity is only provided in epidemiological and experimental studies.

Several studies have indicated that occupational exposure to specific factors, including exposure to benzene, pesticides and mineral fibers is associated with the risk of cancer development (6 and refs. therein). A similar cancer risk has been observed for subjects employed in night shift work, in which both the alterations in the circadian system and the reduction in melatonin output, associated with the exposure to light-at-night 
during night shift work, remain the most valid hypotheses on the causal association between shift work and breast cancer (7).

Furthermore, work organizational factors may also cause cancer. Work-related stress has been suggested to be one of the main factors, followed by sedentary work, including that of video-terminal station workers (8-14). However, stress is only an indirect risk of developing cancer, as certain strategies employed to manage stress may involve excessive smoking, alcohol consumption, overeating and/or the use of drugs, thereby increasing the risk of cancer (15). Boyle et al observed that long-term sedentary work may lead to an increase in the risk of developing colon cancer (16). Apart from the risk of cancer, such physical (17-20) or organizational factors may be also associated with other injuries (21-24).

Work activities associated with the exposure to ionizing and ultraviolet radiation may induce the development of cancer, as well as the development of other diseases. There is also increasing evidence to indicate that specific non-ionising radiation may be linked to the risk of cancer caused by lethal mutations. Outdoor workers can be exposed to ultraviolet radiation from sunlight and may develop melanoma or non-melanoma skin cancers (25). Previous studies, although inconclusive, have suggested the increased risk of brain cancer in subjects exposed to non-ionizing radiation, particularly radio frequency fields emitted by mobile telephones (26). Furthermore, in occupations, such as furnace and smelter operators, or industries such as casting factories, there is some evidence to suggest that heat shock leads to deoxyribonucleic acid (DNA) damage causing cells to switch to high mutation rates for several cell generations (27).

Finally, different infectious agents may cause cancer, either through direct or indirect mechanisms (28-33). In particular, it has been observed that the activation of the immune response may induce specific B-cell clones to proliferate as a consequence of the chronic antigenic stimulation sustained by different infectious agents (34-36).

There is increasing evidence to indicate that the occupational exposure to benzene, pesticides and mineral fibers may be associated with an increased risk of cancer. In this review, such evidence is summarized and discussed in order to determine and identify strategies with which to reduce such risks during work activities.

\section{Benzene}

Benzene is an aromatic hydrocarbon which is widely used in the production of several polymers, resins and synthetic fibers. It is also a component of wood, gasoline and tobacco smoke.

The general population is exposed to benzene through the inhalation of vapors released by motor vehicles, service stations and cigarette smoke. Additionally, contamination can occur due to the ingestion of polluted foods or water. Occupational exposure to benzene occurs in a great number of industrial settings, such as factories, refineries and rubber production plants, as well as shoe manufacturing and printing factories (37). Thus, humans are unavoidably exposed to benzene both in environmental and occupational settings, and this represents a serious concern for public health (38).

Benzene has been classified as a group 1A carcinogen (5), as its toxic effects on the hematopoietic system are well known (39).
Nevertheless, epidemiological and experimental studies have suggested that the exposure to benzene can cause a great number of acute and chronic diseases, which can involve several human tissues or organs. The acute and chronic effects of exposure to benzene can involve the central nervous system (40), the reproductive and developmental system (41-43), the immune system $(44,45)$ and the respiratory system (46). It is widely accepted that benzene can cause hematological diseases, such as acute myeloid leukemia, acute and chronic lymphocytic leukemia, non-Hodgkin's lymphoma, multiple myeloma and aplastic anemia $(47,48)$.

Apart from the fact that benzene can cause cancer of blood components, in animal studies, benzene has also been reported to induce mammary cancer $(49,50)$. However, studies on humans to suggest that benzene is one of the risk factors for the development of breast cancer are limited (51). Few studies have suggested that exposure to benzene can cause malignant melanoma, stomach cancer, prostatic cancer and nasal cancer (52-55). Several potential mechanisms of benzene toxicity have been proposed (56-58). It is generally recognized that its metabolism is critical in the toxicity, with the involvement of one or more reactive metabolites, which are further bioactivated by myeloperoxidases and other heme-protein peroxidases to the reactive compounds emiquinones and quinones (59). These reactive products can lead to the formation of reactive oxygen species (ROS), which can directly damage pivotal molecular targets, such as DNA, lipids and proteins, leading to the formation of new compounds and modified structures, as advanced oxidation protein products (AOPP), advanced glycation end-products (AGE) and advanced lipoperoxidation end-products (ALE) (60), which have been used as biomarkers for risk assessment in workers occupationally exposed to benzene (61). ROS can also affect critical kinases and signal transduction pathways [mitogen-activated protein kinse (MAPK) family, p38-MAPK, nuclear factor (NF)- $\kappa$ B and signal transducer and activator of transcription 3 (STAT3)], involved both in cellular proliferation and apoptosis $(62,63)$. Several authors have demonstrated that the activatation of these pathways promoted by cellular stresses, such as excessive ROS or inflammatory stimuli, may lead to aberrant cell growth and carcinogenesis $(64,65)$. In addition, the link between ROS and several cellular components can promote the formation of DNA strand breaks, sister chromatide exchange (SCE), and micronuclei and chromosomal aberrations (CA) $(66,67)$. Smith et al $(68)$ demonstrated that exposure to benzene was associated with markedly elevated levels of $t(8 ; 21)$ and of hyperdiploidy 8 and 21 in the circulating lymphocytes of otherwise healthy workers exposed to benzene compared to unexposed controls. This suggests a role for these aberrations in benzene-induced leukemia and that their detection in peripheral blood cells by chromosome painting may be useful biomarkers of an increased risk of developing hematological malignancies due to benzene and other potential leukemogens (68).

Bassig et al evaluated alterations in leukocyte telomere length (TL), which is associated with the risk of cancer, in workers occupationally exposed to benzene. The authors observed a significant increase in TL associated with very high levels of benzene exposure in factory workers compared to unexposed control workers (69).

There is evidence to suggest that exposure to benzene is associated with epigenetic alterations $(70,71)$. Epigenetics is the 
investigation of mitotically and meiotically heritable alterations in gene expression without alterations in the DNA sequence. Epigenetic biomarkers, include DNA methylation, histone modifications and microRNA expression, which are induced by exposure to a great number of environmental factors. There also data to suggest an association between exposure to benzene, epigenetic alterations and an increased susceptibility to develop several diseases, such as cancer and inflammatory diseases (72).

Both the toxic and carcinogenic effects of benzene depend on several factors, such as the duration and levels of exposure, the route of exposure (inhalation, ingestion or cutaneous contact) and individual susceptibility factors (age, gender, lifestyle and pre-existing diseases or disorders).

The majority of epidemiological and experimental studies have evaluated the health effects of exposure to high doses of benzene, both in living and working settings. Moreover, a number of studies have referred to an inhalation exposure $(73,74)$, while only in a few cases, exposure by ingestion $(75,76)$ or dermal contact $(77,78)$ has been reported. The progressive reduction of the levels of exposure both in environmental and occupational settings have led researchers to focus their attention on the health effects observed with low doses of benzene, particularly those related to cancer. Further elucidation of the mechanisms through which benzene alters gene expression is required in order to better comprehend the toxic potential of this pollutant and to identify more appropriate preventative measures, particularly for occupationally-exposed subjects.

\section{Pesticides}

Pesticides are chemical compounds which can be distinguished into different classes by chemical structure, target organisms or the type of health hazard produced. They have been widely used to control, repel and destroy any pest both in agricultural and domestic use (79). Thus, it has been hypothesized that exposure to pesticides could be classified as residential, para-occupational and domestic. The first is characterized by living close to a treated field. Domestic exposure is defined as any domestic use by a household member or gardener. Para-occupational exposure is defined as the occupational use of pesticides by one or more household members (80).

Occupational exposure to pesticides occurs during the preparation and handling of pesticides and it is considered greater than that of the general population, which occurs normally at relatively low doses (81). However, the widespread use of pesticides represents a potential risk to human and environmental health. Over the past years, a growing number of epidemiological and experimental studies have evaluated the possible associations between pesticide exposure and the development of adverse health effects. Significant associations between pesticide exposure and cancer have been previously described (51,82-88). However, the exposure to pesticides may also cause the development of other pathological conditions, such as amyotrophic lateral sclerosis (89), asthma (90), type II diabetes (89), and Alzheimer's and Parkinson's disease (92,93).

The knowledge of the association between pesticide exposure and cancerogenesis is actually one of the main challenges in occupational and environmental toxicology. As a carcinogen, a pesticide can act as genotoxic tumor promoter and endocrine disruptor. Pesticides are also considered as chemicals which induce immunotoxicity, influencing the activity of cells, macrophages and the secretion of cytokines, such as interleukin (IL)-17, IL-22, IL-2, IL-8 and interferon (IFN)- $\gamma(94,95)$. These modifications can alter cancer immunosurveillance and can compromise any of the 3 Es of cancer immunoediting: elimination, equilibrium and escape. Moreover, pesticides may promote cancerogenesisby, inducing innate immune dysfunctions, leading to chronic inflammation (96). Among organochlorine pesticides, there are a few still in use (endosulfan, lindane and dicofol) which have been associated with the risk of breast cancer. The study by Fenga demonstrated that organochlorine pesticide mixtures, including aldrin, p,p'-DDE and dichlorodiphenyldichloroethane play a relevant role in the development of breast cancer (51).

Van Maele-Fabry et al investigated the link between prostate cancer and pesticide exposures in manufacturing workers. The results of their study showed that although epidemiological evidence did not allow the identification of a specific pesticide as responsible for an increased risk of prostate cancer, occupational exposure to pesticides emerged as a possible risk factor for this tumor (97).

Lee et al examined the incidence of lung cancer among pesticide applicators exposed to chlorpyrifos. The authors showed a statistically significant increased risk of lung cancer adjusting for cigarette smoke or other confounding factors (98). The same group of researchers investigated a potential correlation between exposure to aldicarb and chlorpyrifos and colorectal cancer, demonstrating a significant association (99).

As regards pancreatic cancer, the available data are controversial. Some authors have demonstrated a possible association between the exposure to pesticides and an increased risk of pancreatic cancer (100), while others have not revealed a consistent association (101). Epidemiological studies have shown that pesticide exposure may increase the risk of developing hepatocellular carcinoma (HCC), through mechanisms of genotoxicity, cytotoxicity, tumor promotion, immunotoxicity and hormonal action (83). In particular, exposure to organochlorine pesticides has been associated with an increased risk of developing HCC among California male residents of agriculturally intensive areas (102). It has also been observed that organochlorine pesticides possess carcinogenicity and can induce liver cancer (103).

A previous study conducted a geo-epidemiological study on a population in Crete in order to understand and relate environmental factors to the pathogenesis of disease. The results of their study revealed a higher than expected spatial distribution of HCC in an area with a widespread use of pesticides (104). As regards the mechanisms through which pesticides can induce HCC, recently, it has been demonstrated that methyl parathion and chlorpyrifos negatively modulate the expression of the paraoxonase 1 (PON1) gene in human HCC (HepG2) cells through a mechanism that involves the induction of inflammatory cytokines, such as tumor necrosis factor (TNF)- $\alpha$, IL-6, and IL-1 $\beta$. A decrease in the expression of the PON1 gene may increase susceptibility to organophosphate intoxication and the risk of diseases related to inflammation and oxidative stress $(79,105)$.

The majority of evidence of the adverse health effects of pesticides in human adults is derived from studies on male 
subjects occupationally exposed to pesticides. Relatively less is known about the pesticide-related health effects in women. This is probably due to the fact that male workers are more engaged in pesticide handling compared to female subjects (95). Furthermore, further limitations can be highlighted, including biological matrices used to estimate exposure and target populations, differences in pesticide exposure levels, distinct ethnicities, age groups and/or dietary characteristics.

Based on these findings, it is important to investigate the health effects of long-term exposure to pesticides, in addition to the acute toxicity data.

\section{Fibers}

Over the past decades, a growing number of scientific evidence has demonstrated the carcinogenic role of asbestos and other mineral fibers, known as asbestos-like fibers, in workers occupationally- or environmentally-exposed to these fibers, such as vitreous, ceramic and organic fibers, suggesting a pathological mechanism based on their physical structure and not only to their chemical function (106).

The first evidence of a causal link between asbestos exposure and development of cancer of the pulmonary apparatus came from Wagner et al that in 1960s, for the first time, described the carcinogenic activity of asbestos fibers in a cohort of workers occupationally exposed to this contaminant (107).

Over the past years, asbestos has been widely used in many industrial contexts for its extraordinary thermal isolation properties. Millions of tons of asbestos have been processed worldwide and used for railway construction, thermal isolation and building construction, making asbestos one of the most widespread contaminants.

The main type of asbestos (90\%) employed in the construction works is the chrysotile, or white asbestos, while amphibolic asbestos, which includes crocidolite and amosite (blue and brown asbestos, respectively), is less used (108). However, the toxic effects of both chrysotile and amphibolic asbestos have been known for 50 years.

Several studies have described the molecular mechanisms that lead to cancer development in individuals exposed to asbestos or asbestos-like fibers. In particular, the inhalation of these fibers has been proven to be responsible for the development of pleural mesothelioma even after a long period of absence of exposure (1079-111).

Indeed, the development of pleural mesothelioma, due asbestos or mineral fiber exposure, is a slow process with a period of latency ranging from 20 to 60 years. For these reasons, the highest worldwide incidence of pleural mesothelioma and lung cancer diseases is estimated to occur in the year 2020, with a peak of incidence for these pathologies in the areas of occupational or environmental exposure to these fibers $(112,113)$.

The most important features for the pathogenic potential of a fiber are the size, diameter and length. In particular, the aerodynamic diameter (Dae) is the major determinant which can be used to predict the toxicity of fibers into the respiratory system (106).

Indeed, fibers ranging from 5 to 10 microns in length can reach the interstitial and serous lung, where they cause severe injury in the form of interstitial and pleural fibrosis, thickening and pleural plaques, as well as tumors. Fibers longer than
10 microns, stop at the alveolar level where they can cause asbestos-related alveolitis $(114,115)$.

Another mineral fiber with asbestos-like effects is fluoroedenite (FE). FE is a mineral fiber of volcanic origin from the calcic clino-amphibole subgroup, similar to amphibole tremolite and actinolite antophyllite (116).

FE was firstly identified in 1997 near the area of Biancavilla, in eastern Sicily. For years, this mineral was extracted from Mount Calvario and used for the construction of houses in the urban areas near Mount Etna (117,118).

In particular, various types of airborne mineral fibers were identified in the volcanic area of Mount Etna and may represent the cause of the increased incidence of mesothelioma and lung cancer and other lung diseases (119).

Although currently a clean correlation between the amount of inhaled fibers and the occurrence of related diseases has not been demonstrated, several studies and meta-analyses have suggest a dose-risk linear without a threshold effect (120 and refs. therein).

Several studies have provided strong evidence that the development of malignant mesothelioma is associated with asbestos and asbestos-like fibers, particularly amphibole asbestos (121 and refs. therein).

The early detection of asbestos-related diseases is one of the major goals of health surveillance in workers exposed to mineral fibers (122). However, the protocols adopted for workers exposed to asbestos do not have sufficient specificity and sensitivity to ensure early diagnosis (123). Even the IARC highlighted that occupational and environmental exposure to mineral fibers is the leading cause of asbestos-like and asbestos-induced disease $(124,125)$.

The mechanisms that lead to the development of mesothelioma in patients exposed to mineral fibers are still not completely known. Recently, it has been shown that in subjects exposed to such fibers, tumor expansion is associated with the activation of fibulin-3 (126). High levels of fibulin-3 were detected in plasma samples of street cleaners from Biancavilla (Sicily), which are at high risk of FE exposure (126).

Intriguingly, it was demonstrated that plasma levels of fibulin-3 were significantly lower in the group of workers exposed to asbestos fibers compared to those exposed to FE (126), suggesting that asbestos disposal workers properly used the personal protective equipment according to the current regulations. By contrast, other workers, such as street cleaners exhibited high levels of fibulin-3, indicating that these workers should be better equipped in order to prevent injury caused by FE found in dust deposited on the ground (126).

Accordingly, our most recent in vitro study indicated that fibulin-3 was overexpressed in mesothelial cells following treatment with $\mathrm{FE}$ and not following treatment with other particulates at both the transcript and protein level (126). Therefore, it was hypothesized that the detection of high plasma levels of fibulin-3, observed in street cleaners from the Biancavilla area, may be due to FE exposure. However, volcanic particulate exposure did not affect fibulin-3 expression (126,127).

The development of mesothelioma is not only directly caused by exposure to mineral fibers. Chronic exposure to asbestos-like fibers may cause chronic inflammation and hence pro-carcinogenic stimuli (128). Chronic inflammation results in the production of several cytokines and growth factors that promote cellular proliferation and inhibit apoptosis $(128,129)$. 
It has also been demonstrated that p27 is downregulated in mesothelial cells follwoing treatment with FE fibers (130). Notably, p27 is considered a tumor suppressor gene due to its function as a regulator of the cell cycle and in cancer it is often inactivated (131). It has also been demonstrated that low levels of p27 are associated with stathmin upregulation, determining an aggressive phenotype of tumor cells (131). Our previous computational evaluation showed that stathmin is overexpressed in lung cancer patients with a history of asbestos exposure compared with those not exposed to any fibers (126). Accordingly, we can speculate that both fibulin-3 overexpression and stathmin activation may be the underlying mechanisms reponsible for the transformation of mesothelial cells following exposure to mineral fibers.

Apart from conventional risk factors described above, nanomaterials, such as carbon nanotubes may also represent emerging risk factors for cancer development (132). Long-term animal studies demonstrated that the intratracheal instillation of nanostructured carbon black, aluminium silicate, aluminium oxide, titanium dioxide (hydrophilic and hydrophobic) and amorphous silicon dioxide resulted in tumors induced by all tested nanomaterials (132 and refs. therein). A fraction of these carbon nanotubes may lead to asbestos-like effects. Former investigations suggested that lung tumors occur in cases of lung overload and subsequent reactions, such as inflammation and fibrosis. Accordingly, tumor development depends on pre-cancerous lesions, including inflammation and fibrosis. However, other studies support the notion that such particles directly interact with DNA, causing molecular alterations and in turn, tumor formation (132 and refs. therein).

\section{Conclusions}

The correlation between occupational exposure and the development of cancer is of particular interest to several investigators. In addition to work exposure risk factors, cancer may be caused by incorrect life style habits, as previously observed (133).

Environmental and occupational exposure to hazardous stimuli has been linked to the development of several types of cancer (4). These environmental stimuli may involve the p53, Raf/MEK/ERK and PI3K/AKT pathways in solid and hematological cancers, providing further insight into the mechanisms responsible for malignant transformation (134-136). On the other hand, chronic exposure to occupational carcinogens can modulate the immune system response, leading to an increase in the production of cytokines and inflammatory cytokines. These molecules promote the occurrence of a chronic inflammation status that that could lead to the development of tumors $(96,137)$.

The present review aimed to determine the association between the exposure to occupational carcinogens and the development of cancer, and the impact that these contaminants may have on public health. However, the evaluation of exposure levels to a carcinogen is challenging. Exposure levels can vary widely under the same conditions widely according to physical or environmental factors. Even between individuals in the same workplace there are exposure variations. On these bases, several studies have indicated that a worker's specific employment is one of the most important elements for personal exposure that could determine significant variations from the estimated exposure values based on environmental data or epidemiological data. In our opinion, this indicates that previous evaluations based on registers or questionnaires may be considered not completely reliable.

Future studies aimed to highlight the real correlation between environmental and occupational exposure to risk factors should use an objective method for the assessment of carcinogen exposure levels. These procedures may ensure a better health surveillance and a more effective evaluation of the risk in exposed workers.

\section{References}

1. Brown JR and Thornton JL: Percivall Pott (1714-1788) and chimney sweepers' cancer of the scrotum. Br J Ind Med 14: 68-70, 1957.

2. Muller H: The problem of genetic modification. In: Proceedings of the Fifth International Congress of Genetics in Berlin. Berlin, 1926.

3. Siemiatycki J, Richardson L, Straif K, Latreille B, Lakhani R, Campbell S, Rousseau MC and Boffetta P: Listing occupational carcinogens. Environ Health Perspect 112: 1447-1459, 2004.

4. Boffetta $P$ and Nyberg F: Contribution of environmental factors to cancer risk. Br Med Bull 68: 71-94, 2003.

5. Blair A, Marrett L and Beane Freeman L: Occupational cancer in developed countries. Environ Health 10 (Suppl 1): S9, 2011.

6. Chappell G, Pogribny IP, Guyton KZ and Rusyn I: Epigenetic alterations induced by genotoxic occupational and environmental human chemical carcinogens: A systematic literature review. Mutat Res Rev Mutat Res 768: 27-45, 2016.

7. Leonardi GC, Rapisarda V, Marconi A, Scalisi A, Catalano F, Proietti L, Travali S, Libra M and Fenga C: Correlation of the risk of breast cancer and disruption of the circadian rhythm (Review). Oncol Rep 28: 418-428, 2012.

8. Fenga C, Aragona P, Di Nola C and Spinella R: Comparison of ocular surface disease index and tear osmolarity as markers of ocular surface dysfunction in video terminal display workers. Am J Ophthalmol 158: 41-48.e2, 2014.

9. Fenga C, Virelli L, Fenga P, Rapisarda V, Di Nola C and Virelli A: Work related low-back pain: Prevention and strategies of rehabilitation. G Ital Med Lav Ergon 29 (Suppl 3): 586-587, 2007 (In Italian).

10. Fenga C, Aragona P, Cacciola A, Spinella R, Di Nola C, Ferreri F and Rania L: Meibomian gland dysfunction and ocular discomfort in video display terminal workers. Eye (Lond) 22: 91-95, 2008.

11. Fenga $\mathrm{C}$ and Barbaro M: Work and eye discomfort: Relationship between symptoms and signs of conjunctival changes. A protocol for health surveillance. G Ital Med Lav Ergon 22: 265-268, 2000 (In Italian).

12. Fenga C, Di Pietro R, Fenga P, Di Nola C, Spinella R, Cacciola A, Germanò D and Aragona P: Asthenopia in VDT users: Our experience. G Ital Med Lav Ergon 29 (Suppl): 500-501, 2007 (In Italian).

13. Fenga C, Cacciola A, Anzalone C, Trimarchi G and Grillo OC: Influence of microclimate factors on ocular discomfort in video display terminal workers. G Ital Med Lav Ergon 27: 417-421, 2005 (In Italian).

14. Fenga C, Cacciola A, Aragona P, Spinella R, Ricciardo Calderaro $\mathrm{S}$ and Germanò $\mathrm{D}$ : Work and video terminals: Eye discomfort and blepharitis. Preliminary data. G Ital Med Lav Ergon 25 (Suppl 3): 208-209, 2003 (In Italian).

15. Schmidt A, Neumann M, Wirtz M, Ernstmann N, StaratschekJox A, Stoelben E, Wolf J and Pfaff H. The influence of occupational stress factors on the nicotine dependence: a cross sectional study. Tob Induc Dis 8: 6, 2010.

16. Boyle T, Fritschi L, Heyworth J and Bull F: Long-term sedentary work and the risk of subsite-specific colorectal cancer. Am J Epidemiol 173: 1183-1191, 2011.

17. Valentino M, Rapisarda V and Fenga C: Hand injuries due to high-pressure injection devices for painting in shipyards: Circumstances, management, and outcome in twelve patients. Am J Ind Med 43: 539-542, 2003.

18. Fenga C, Rapisarda V, Valentino M, Cacciola A, Deboli R, Calvo A and Germanò D: Hand-arm vibration syndrome and upper limbs diseases in the forest workers of Italia meridionale. G Ital Med Lav Ergon 29 (Suppl 3): 592-593, 2007 (In Italian). 
19. Rapisarda V, Valentino M,Bolognini S and Fenga C: Noise-related occupational risk aboard fishing vessels: Considerations on prevention and the protection of exposed workers. G Ital Med Lav Ergon 26: 191-196, 2004 (In Italian).

20. Valentino M, Rapisarda V, Scalise L, Paone N, Santarelli L, Fenga $\mathrm{C}$ and Rossi GL: A new method for the experimental assessment of finger haemodynamic effects induced by a hydraulic breaker in operative conditions. J Occup Health 46 253-259, 2004.

21. Di Rosa AE, Gangemi S, Cristani M, Fenga C, Saitta S, Abenavoli E, Imbesi S, Speciale A, Minciullo PL, Spatari $\approx$ G, et al: Serum levels of carbonylated and nitrosylated proteins in mobbing victims with workplace adjustment disorders. Biol Psychol 82: 308-311, 2009.

22. Fenga C, Faranda M, Aragona M, Micali E, Di Nola C, Trimarchi G, Crimi B and Cacciola A: Burnout and occupational stress in nurses. Med Lav 98: 55-63, 2007 (In Italian).

23. Fenga C, Di Nola C, Maviglia P, Cacciola A and Nardella C: Assessment of occupational stress among shopping centre employees. G Ital Med Lav Ergon 31 (Suppl B): B56-B63, 2009 (In Italian)

24. Fenga C, Micali E, Cacciola A, Trimarchi G and Germanò D: Stressful life events and fibrinogen level in middle-aged teachers. Psychopathology 37: 64-68, 2004.

25. Candido S, Rapisarda V, Marconi A, Malaponte G, Bevelacqua V, Gangemi P, Scalisi A, McCubrey JA, Maestro R, Spandidos DA, et al: Analysis of the $B-R a f^{\mathrm{V} 600 \mathrm{E}}$ mutation in cutaneous melanoma patients with occupational sun exposure. Oncol Rep 31: 1079-1082, 2014.

26. Clapp RW, Jacobs MM and Loechler EL: Environmental and occupational causes of cancer: New evidence 2005-2007. Rev Environ Health 23: 1-37, 2008.

27. Fabre $\mathrm{F}$ and Roman $\mathrm{H}$ : Genetic evidence for inducibility of recombination competence in yeast. Proc Natl Acad Sci USA 74: $1667-1671,1977$.

28. Fenga C, Gangemi S, De Luca A, Calimeri S, Lo Giudice D, Pugliese M, Licitra F, Alibrandi A and Costa C: Seroprevalence and occupational risk survey for Coxiella burnetii among exposed workers in Sicily, Southern Italy. Int J Occup Med Environ Health 28: 901-907, 2015.

29. Fenga $C$ and Pugliese M: Endemic zoonosis in Mediterranean area. G Ital Med Lav Ergon 35: 347-349, 2013 (In Italian).

30. Rapisarda V, Valentino M, Ravalli P, Fenga C and Duscio D: Occupational brucellosis in slaughtering of sheep and goats: Study of five cases from a municipal abattoir in south-eastern Sicily. Med Lav 96: 134-141, 2005 (In Italian).

31. Rapisarda V, Marconi A, Candido S, Nicolosi D, Salmeri M, Gangemi P, Proietti L, Spandidos DA, Bracci M, Fenga C, et al: A tailored health surveillance program unveils a case of MALT lymphoma in an HCV-positive health-care worker. Oncol Lett 5: 651-654, 2013.

32. Ioli A, Lo Giudice L and Fenga C: Skin manifestations of parasites in occupational diseases. G Ital Med Lav Ergon 24 202-204, 2002 (In Italian).

33. Fenga C, Cacciola A, Di Nola C, Calimeri S, Lo Giudice D, Pugliese M, Niutta PP and Martino LB: Serologic investigation of the prevalence of Chlamydophila psittaci in occupationally exposed subjects in eastern Sicily. Ann Agric Environ Med 14 93-96, 2007.

34. Libra M, Mangano K, Anzaldi M, Quattrocchi C, Donia M, di Marco R, Signorelli S, Scalia G, Zignego AL, de Re V, et al Analysis of interleukin (IL)-1 $\beta$ IL-1 receptor antagonist, soluble IL-1 receptor type II and IL-1 accessory protein in HCV-associated lymphoproliferative disorders. Oncol Rep 15: 1305-1308, 2006.

35. Libra M, Polesel J, Russo AE, De Re V, Cinà D, Serraino D, Nicoletti F, Spandidos DA, Stivala F and Talamini R: Extrahepatic disorders of $\mathrm{HCV}$ infection: a distinct entity of B-cell neoplasia? Int J Oncol 36: 1331 1340, 2010.

36. Ferreri AJ, Dolcetti R, Magnino S, Doglioni C and Ponzoni M: Chlamydial infection: the link with ocular adnexal lymphomas. Nat Rev Clin Oncol 6: 658-669, 2009.

37. Bahadar H,Mostafalou S and Abdollahi M: Current understandings and perspectives on non-cancer health effects of benzene: A global concern. Toxicol Appl Pharmacol 276: 83-94, 2014.

38. Fenga C, Catania C, Di Nola C, Cacciola A, Germanò D and Costa C: Air pollution in urban areas as a risk factor for health in the general population and in workers. Environmental and biologic monitoring of 1-3 butadiene. G Ital Med Lav Ergon 29 (Suppl 3): 861-863, 2007 (In Italian).
39. Lan Q, Zhang L, Li G, Vermeulen R, Weinberg RS, Dosemeci M, Rappaport SM, Shen M, Alter BP, Wu Y, et al: Hematotoxicity in workers exposed to low levels of benzene. Science 306: $1774-1776,2004$

40. Kanada M, Miyagawa M, Sato M, Hasegawa H and Honma T: Neurochemical profile of effects of 28 neurotoxic chemicals on the central nervous system in rats (1). Effects of oral administration on brain contents of biogenic amines and metabolites. Ind Health 32: 145-164, 1994

41. IARC Working Group on the Evaluation of Carcinogenic Risks to Humans: Occupational exposures in petroleum refining; crude oil and major petroleum fuels. IARC Monogr Eval Carcinog Risks Hum 45: 1-322, 1989.

42. Reutman SR, LeMasters GK, Knecht EA, Shukla R, Lockey JE, Burroughs GE and Kesner JS: Evidence of reproductive endocrine effects in women with occupational fuel and solvent exposures. Environ Health Perspect 110: 805-811, 2002.

43. Marchetti F, Eskenazi B, Weldon RH, Li G, Zhang L, Rappaport SM, Schmid TE, Xing C, Kurtovich E and Wyrobek AJ: Occupational exposure to benzene and chromosomal structural aberrations in the sperm of Chinese men. Environ Health Perspect 120: 229-234, 2012.

44. Smith MT: Advances in understanding benzene health effects and susceptibility. Annu Rev Public Health 31: 133-148, 2, 148 , 2010.

45. Uzma N, Kumar BS and Hazari MA: Exposure to benzene induces oxidative stress, alters the immune response and expression of p53 in gasoline filling workers. Am J Ind Med 53: $1264-1270,2010$

46. Winek CL and Collom WD: Benzene and toluene fatalities. J Occup Med 13: 259-261, 1971.

47. Collins JJ, Ireland B, Buckley CF and Shepperly D: Lymphohaematopoeitic cancer mortality among workers with benzene exposure. Occup Environ Med 60: 676-679, 2003.

48. Snyder R: Leukemia and benzene. Int J Environ Res Public Health 9: 2875-2893, 2012.

49. Bennett LM and Davis BJ: Identification of mammary carcinogens in rodent bioassays. Environ Mol Mutagen 39: 150-157, 2002.

50. Rudel RA, Attfield KR, Schifano JN and Brody JG: Chemicals causing mammary gland tumors in animals signal new directions for epidemiology, chemicals testing, and risk assessment for breast cancer prevention. Cancer 109: 2635-2666, 2007.

51. Fenga C: Occupational exposure and risk of breast cancer. Biomed Rep 4: 282-292, 2016.

52. Collingwood KW, Raabe GK and Wong O: An updated cohort mortality study of workers at a northeastern United States petroleum refinery. Int Arch Occup Environ Health 68: 277-288, 1996.

53. Fu H, Demers PA, Costantini AS, Winter P, Colin D, Kogevinas M and Boffetta P: Cancer mortality among shoe manufacturing workers: An analysis of two cohorts. Occup Environ Med 53: 394-398, 1996.

54. Gérin M, Siemiatycki J, Désy M and Krewski D: Associations between several sites of cancer and occupational exposure to benzene, toluene, xylene, and styrene: Results of a case-control study in Montreal. Am J Ind Med 34: 144-156, 1998.

55. Lewis RJ, Schnatter AR, Drummond I, Murray N, Thompson FS, Katz AM, Jorgensen G, Nicolich MJ, Dahlman D and Thériault G: Mortality and cancer morbidity in a cohort of Canadian petroleum workers. Occup Environ Med 60: 918-928, 2003.

56. Snyder R, Witz G and Goldstein BD: The toxicology of benzene. Environ Health Perspect 100: 293-306, 1993.

57. Zhang L, McHale CM, Rothman N, Li G, Ji Z, Vermeulen R, Hubbard AE, Ren X, Shen M, Rappaport SM, et al: Systems biology of human benzene exposure. Chem Biol Interact 184: 86-93, 2010.

58. Nishikawa T, Izumo K, Miyahara E, Horiuchi M, Okamoto Y, Kawano Y and Takeuchi T: Benzene induces cytotoxicity without metabolic activation. J Occup Health 53: 84-92, 2011.

59. Wan J, Badham HJ and Winn L: The role of c-MYB in benzene-initiated toxicity. Chem Biol Interact 153-154: 171-178, 2005.

60. Kalousová M, Zima T, Tesar V, Dusilová-Sulková S and Skrha J: Advanced glycoxidation end products in chronic diseases-clinical chemistry and genetic background. Mutat Res 579: 37-46, 2005.

61. Costa C, Ozcagli E, Gangemi S, Schembri F, Giambò F, Androutsopoulos V, Tsatsakis A and Fenga C: Molecular biomarkers of oxidative stress and role of dietary factors in gasoline station attendants. Food Chem Toxicol 90: 30-35, 2016. 
62. Malaponte G, Signorelli SS, Bevelacqua V, Polesel J, Taborelli M, Guarneri C, Fenga C, Umezawa K and Libra M: Increased Levels of NF- $\kappa \mathrm{B}$-Dependent Markers in Cancer-Associated Deep Venous Thrombosis. PLoS One 10: e0132496, 2015.

63. Fenga C, Gangemi S, Giambò F, Tsitsimpikou C, Golokhvast K, Tsatsakis A and Costa C: Low-dose occupational exposure to benzene and signal transduction pathways involved in the regulation of cellular response to oxidative stress. Life Sci 147: 67-70, 2016.

64. Badham HJ, Renaud SJ, Wan J and Winn LM: Benzene-initiated oxidative stress: Effects on embryonic signaling pathways. Chem Biol Interact 184: 218-221, 2010.

65. Stokes SE and Winn LM: NF- $\kappa B$ signaling is increased in HD3 cells following exposure to 1,4-benzoquinone: Role of reactive oxygen species and p38-MAPK. Toxicol Sci 137: 303-310, 2014.

66. Barreto G, Madureira D, Capani F, Aon-Bertolino L, Saraceno E and Alvarez-Giraldez LD: The role of catechols and free radicals in benzene toxicity: An oxidative DNA damage pathway. Environ Mol Mutagen 50: 771-780, 2009.

67. Lacquaniti A, Fenga C, Venuti VA, Pernice L, Catanzariti S, Sirna G, Pernice F, Arena A, Lupica R, Abbate C, et al: Hydrocarbons and kidney damage: Potential use of neutrophil gelatinase-associated lipocalin and sister chromatide exchange. Am J Nephrol 35: 271-278, 2012

68. Smith MT, Zhang L, Wang Y, Hayes RB, Li G, Wiemels J, Dosemeci M, Titenko-Holland N, Xi L, Kolachana P, et al: Increased translocations and aneusomy in chromosomes 8 and 21 among workers exposed to benzene. Cancer Res 58: 2176-2181, 1998.

69. Bassig BA, Zhang L, Cawthon RM, Smith MT, Yin S, Li G, $\mathrm{Hu}$ W, Shen M, Rappaport S, Barone-Adesi F, et al: Alterations in leukocyte telomere length in workers occupationally exposed to benzene. Environ Mol Mutagen 55: 673-678, 2014.

70. Bollati V, Baccarelli A, Hou L, Bonzini M, Fustinoni S Cavallo D, Byun HM, Jiang J, Marinelli B, Pesatori AC, et al: Changes in DNA methylation patterns in subjects exposed to low-dose benzene. Cancer Res 67: 876-880, 2007.

71. Bai W, Chen Y, Yang J, Niu P, Tian L and Gao A: Aberrant miRNA profiles associated with chronic benzene poisoning. Exp Mol Pathol 96: 426-430, 2014.

72. Fenga C, Gangemi S and Costa C: Benzene exposure is associated with epigenetic changes (Review). Mol Med Rep 13: 3401-3405, 2016

73. Abubakar MB, Abdullah WZ, Sulaiman SA and Ang BS: The effects of exposure to petrol vapours on growth, haematological parameters and oxidative markers in sprague-dawley male rats. Malays J Med Sci 22: 23-31, 2015.

74. Cruz-Martinez L, Smits JE and Fernie K: Stress response, biotransformation effort, and immunotoxicity in captive birds exposed to inhaled benzene, toluene, nitrogen dioxide, and sulfur dioxide. Ecotoxicol Environ Saf 112: 223-230, 2015.

75. Harada $K$, Ichiyama $T$, Ikeda $H$ and Yoshida $K$ : A fatal case of oral ingestion of benzine. Am J Forensic Med Pathol 20: 84-89, 1999.

76. López E, Schuhmacher M and Domingo JL: Human health risks of petroleum-contaminated groundwater. Environ Sci Pollut Res Int 15: 278-288, 2008

77. Bogen KT and Sheehan PJ: Dermal versus total uptake of benzene from mineral spirits solvent during parts washing. Risk Anal 34: 1336-1358, 2014.

78. Williams PR, Sahmel J, Knutsen J, Spencer J and Bunge AL: Dermal absorption of benzene in occupational settings: Estimating flux and applications for risk assessment. Crit Rev Toxicol 41: 111-142, 2011

79. Costa C, Gangemi S, Giambò F, Rapisarda V, Caccamo D and Fenga C: Oxidative stress biomarkers and paraoxonase 1 polymorphism frequency in farmers occupationally exposed to pesticides. Mol Med Rep 12: 6353-6357, 2015.

80. Salameh PR, Baldi I, Brochard P, Raherison C, Abi Saleh B and Salamon R: Respiratory symptoms in children and exposure to pesticides. Eur Respir J 22: 507-512, 2003.

81. García-García CR, Parrón T, Requena M, Alarcón R, Tsatsakis AM and Hernández AF: Occupational pesticide exposure and adverse health effects at the clinical, hematological and biochemical level. Life Sci 145: 274-283, 2016.

82. Alavanja MC, Samanic C, Dosemeci M, Lubin J, Tarone R, Lynch CF, Knott C, Thomas K, Hoppin JA, Barker J, et al: Use of agricultural pesticides and prostate cancer risk in the Agricultural Health Study cohort. Am J Epidemiol 157: 800-814, 2003.
83. Gomaa AI, Khan SA, Toledano MB, Waked I and Taylor-Robinson SD: Hepatocellular carcinoma: Epidemiology, risk factors and pathogenesis. World J Gastroenterol 14: 4300-4308, 2008

84. Santibañez M, Alguacil J, de la Hera MG, Navarrete-Muñoz EM, Llorca J, Aragonés N, Kauppinen T and Vioque J; PANESOES Study Group: Occupational exposures and risk of stomach cancer by histological type. Occup Environ Med 69: 268-275, 2012.

85. Vakonaki E, Androutsopoulos VP, Liesivuori J, Tsatsakis AM and Spandidos DA: Pesticides and oncogenic modulation. Toxicology 307: 42-45, 2013.

86. Purdue MP, Hoppin JA, Blair A, Dosemeci M and Alavanja MC: Occupational exposure to organochlorine insecticides and cancer incidence in the Agricultural Health Study. Int J Cancer 120: 642-649, 2007

87. Navaranjan G, Hohenadel K, Blair A, Demers PA, Spinelli JJ, Pahwa P, McLaughlin JR, Dosman JA, Ritter L and Harris SA: Exposures to multiple pesticides and the risk of Hodgkin lymphoma in Canadian men. Cancer Causes Control 24: 1661-1673, 2013

88. Kachuri L, Demers PA, Blair A, Spinelli JJ, Pahwa M, McLaughlin JR, Pahwa P, Dosman JA and Harris SA: Multiple pesticide exposures and the risk of multiple myeloma in Canadian men. Int J Cancer 133: 1846-1858, 2013.

89. Kang H, Cha ES, Choi GJ and Lee WJ: Amyotrophic lateral sclerosis and agricultural environments: A systematic review. J Korean Med Sci 29: 1610-1617, 2014

90. Mamane A, Baldi I, Tessier JF, Raherison C and Bouvier G: Occupational exposure to pesticides and respiratory health. Eur Respir Rev 24: 306-319, 2015.

91. Song Y, Chou EL, Baecker A, You NC, Song Y, Sun Q and Liu S: Endocrine-disrupting chemicals, risk of type 2 diabetes, and diabetes-related metabolic traits: A systematic review and meta-analysis. J Diabetes 8: 516-532, 2016

92. Taetzsch T and Block ML: Pesticides, microglial NOX2, and Parkinson's disease. J Biochem Mol Toxicol 27: 137-149, 2013.

93. Richardson JR, Roy A, Shalat SL, von Stein RT, Hossain MM, Buckley B, Gearing M, Levey AI and German DC: Elevated serum pesticide levels and risk for Alzheimer disease. JAMA Neurol 71: 284-290, 2014.

94. Costa C, Rapisarda V, Catania S, Di Nola C, Ledda C and Fenga C: Cytokine patterns in greenhouse workers occupationally exposed to $\alpha$-cypermethrin: An observational study. Environ Toxicol Pharmacol 36: 796-800, 2013.

95. Fenga C, Gangemi S, Catania S, De Luca A and Costa C: IL-17 and IL-22 serum levels in greenhouse workers exposed to pesticides. Inflamm Res 63: 895-897, 2014.

96. Gangemi S, Gofita E, Costa C, Teodoro M, Briguglio G, Nikitovic D, Tzanakakis G, Tsatsakis AM, Wilks MF, Spandidos DA, et al: Occupational and environmental exposure to pesticides and cytokine pathways in chronic diseases (Review). Int J Mol Med 38: 1012-1020, 2016.

97. Van Maele-Fabry G, Libotte V, Willems J and Lison D: Review and meta-analysis of risk estimates for prostate cancer in pesticide manufacturing workers. Cancer Causes Control 17: 353-373, 2006

98. Lee WJ, Blair A, Hoppin JA, Lubin JH, Rusiecki JA, Sandler DP, Dosemeci $\mathrm{M}$ and Alavanja MC: Cancer incidence among pesticide applicators exposed to chlorpyrifos in the Agricultural Health Study. J Natl Cancer Inst 96: 1781-1789, 2004.

99. Lee WJ, Sandler DP, Blair A, Samanic C, Cross AJ and Alavanja MC: Pesticide use and colorectal cancer risk in the Agricultural Health Study. Int J Cancer 121: 339-346, 2007.

100. Antwi SO, Eckert EC, Sabaque CV, Leof ER, Hawthorne KM, Bamlet WR, Chaffee KG, Oberg AL and Petersen GM: Exposure to environmental chemicals and heavy metals, and risk of pancreatic cancer. Cancer Causes Control 26: 1583-1591, 2015.

101. Fritschi L, Benke G, Risch HA, Schulte A, Webb PM, Whiteman DC, Fawcett J and Neale RE: Occupational exposure to N-nitrosamines and pesticides and risk of pancreatic cancer. Occup Environ Med 72: 678-683, 2015.

102. VoPham T, Brooks MM, Yuan JM, Talbott EO, Ruddell D, Hart JE, Chang CC and Weissfeld JL: Pesticide exposure and hepatocellular carcinoma risk: A case-control study using a geographic information system (GIS) to link SEER-Medicare and California pesticide data. Environ Res 143 (Pt A): 68-82, 2015. 
103. Niu J, Lin Y, Guo Z, Niu M and Su C: The Epidemiological Investigation on the Risk Factors of Hepatocellular Carcinoma: A Case-Control Study in Southeast China. Medicine (Baltimore) 95: e2758, 2016.

104.Sifaki-Pistolla D, Karageorgos SA, Koulentaki M, Samonakis D, Stratakou S, Digenakis E and Kouroumalis E: Geoepidemiology of hepatocellular carcinoma in the island of Crete, Greece. A possible role of pesticides. Liver Int 36: 588-594, 2016.

105. Medina-Díaz IM, Ponce-Ruiz N, Ramírez-Chávez B, Rojas-García AE, Barrón-Vivanco BS, Elizondo G and Bernal-Hernández YY: Downregulation of human paraoxonase 1 (PON1) by organophosphate pesticides in HepG2 cells. Environ Toxicol: Mar 7, 2016 (Epub ahead of print).

106. Stanton MF, Layard M, Tegeris A, Miller E, May M, Morgan E and Smith A: Relation of particle dimension to carcinogenicity in amphibole asbestoses and other fibrous minerals. J Natl Cancer Inst 67: 965-975, 1981

107. Wagner JC, Sleggs CA and Marchand P: Diffuse pleural mesothelioma and asbestos exposure in the North Western Cape Province. Br J Ind Med 17: 260-271, 1960.

108. Tweedale G: Asbestos and its lethal legacy. Nat Rev Cancer 2: 311-315, 2002

109. McDonald JC: Epidemiology of malignant mesothelioma - an outline. Ann Occup Hyg 54: 851-857, 2010.

110. Britton M: The epidemiology of mesothelioma. Semin Oncol 29: $18-25,2002$

111. Mensi C, De Matteis S, Dallari B, Riboldi L, Bertazzi PA and Consonni D: Incidence of mesothelioma in Lombardy, Italy: Exposure to asbestos, time patterns and future projections. Occup Environ Med 73: 607-613, 2016.

112. Tan C and Treasure T: Mesothelioma: Time to take stock. J R Soc Med 98: 455-458, 2005.

113. Robinson BW and Lake RA: Advances in malignant mesothelioma. N Engl J Med 353: 1591-1603, 2005.

114. Barbieri PG and Sommigliana AB: Asbestos-related diseases and biological index of cumulative dose in shipyard workers (1996-2015). Med Lav 107: 315-326, 2016 (In Italian).

115. Norbet C, Joseph A, Rossi SS, Bhalla S and Gutierrez FR: Asbestos-related lung disease: A pictorial review. Curr Probl Diagn Radiol 44: 371-382, 2015.

116. Comba P, Gianfagna A and Paoletti L: Pleural mesothelioma cases in Biancavilla are related to a new fluoro-edenite fibrous amphibole. Arch Environ Health 58: 229-232, 2003.

117. Bruni BM, Pacella A, MazziottiTagliani S, Gianfagna A and Paoletti L: Nature and extent of the exposure to fibrous amphiboles in Biancavilla. Sci Total Environ 370: 9-16, 2006.

118. Putzu MG, Bruno C, Zona A, Massiccio M, Pasetto R, Piolatto PG and Comba P: Fluoro-edenitic fibres in the sputum of subjects from Biancavilla (Sicily): A pilot study. Environ Health 5: 20, 2006.

119. Paoletti L, Batisti D, Bruno C, Di Paola M, Gianfagna A, Mastrantonio M, Nesti $\mathrm{M}$ and Comba P: Unusually high incidence of malignant pleural mesothelioma in a town of eastern Sicily: An epidemiological and environmental study. Arch Environ Health 55: 392-398, 2000.

120. Hodgson JT and Darnton A: The quantitative risks of mesothelioma and lung cancer in relation to asbestos exposure. Ann Occup Hyg 44: 565-601, 2000.

121. Carbone M, Ly BH, Dodson RF, Pagano I, Morris PT, Dogan UA, Gazdar AF, Pass HI and Yang H: Malignant mesothelioma: Facts, myths, and hypotheses. J Cell Physiol 227: 44-58, 2012.

122. Cristaudo A, Foddis R and Guglielmi G: Methodology and results of an experience of medical surveillance of people previously exposed to asbestos in Tuscany. G Ital Med Lav Ergon 32 (Suppl 4): 385-388, 2010 (In Italian).
123. Marcus PM, Bergstralh EJ, Fagerstrom RM, Williams DE, Fontana R, Taylor WF and Prorok PC: Lung cancer mortality in the Mayo Lung Project: Impact of extended follow-up. J Natl Cancer Inst 92: 1308-1316, 2000.

124. International Agency for Research on Cancer (IARC): IARC monographs on the evaluation of carcinogenic risks to humans. IARC, Lyon, pp1-42, 1987.

125. Institute of Medicine (US) Committee on Asbestos: Selected Health Effects: Asbestos: Selected Cancers. National Academies Press, Washington, DC, 2006.

126. Rapisarda V, Salemi R, Marconi A, Loreto C, Graziano AC, Cardile V, Basile MS, Candido S, Falzone L, Spandidos DA, et al: Fluoro-edenite induces fibulin-3 overexpression in non-malignant human mesothelial cells. Oncol Lett 12: 3363-3367, 2016.

127. Rapisarda V, Ledda C, Migliore M, Salemi R, Musumeci A, Bracci M, Marconi A, Loreto C and Libra M: FBLN-3 as a biomarker of pleural plaques in workers occupationally exposed to carcinogenic fibers: A pilot study. Future Oncol 11 (Suppl 24): 35-37, 2015.

128. Cardile V, Lombardo L, Belluso E, Panico A, Renis M, Gianfagna A and Balazy M: Fluoro-edenite fibers induce expression of Hsp70 and inflammatory response. Int J Environ Res Public Health 4: 195-202, 2007.

129. Loreto C, Rapisarda V, Carnazza ML, Musumeci G, Valentino M, Fenga $\mathrm{C}$ and Martinez G: Fluoro-edenite fibres induce lung cell apoptosis: An in vivo study. Histol Histopathol 23: 319-326, 2008.

130. Musumeci G, Cardile V, Fenga C, Caggia S and Loreto C: Mineral fibre toxicity: Expression of retinoblastoma $(\mathrm{Rb})$ and phospho-retinoblastoma $(\mathrm{pRb})$ protein in alveolar epithelial and mesothelial cell lines exposed to fluoro-edenite fibres. Cell Biol Toxicol 27: 217-225, 2011.

131. Chu IM, Hengst L and Slingerland JM: The Cdk inhibitor p27 in human cancer: Prognostic potential and relevance to anticancer therapy. Nat Rev Cancer 8: 253-267, 2008.

132. Miozzi E, Rapisarda V, Marconi A, Costa C, Polito I, Spandidos DA, Libra M and Fenga C: Fluoro-edenite and carbon nanotubes: The health impact of 'asbestos-like' fibres (Review). Exp Ther Med 11: 21-27, 2016.

133. Polesel J, Franceschi S, Talamini R, Negri E, Barzan L, Montella M, Libra M, Vaccher E, Franchin G, La Vecchia C, et al: Tobacco smoking, alcohol drinking, and the risk of different histological types of nasopharyngeal cancer in a low-risk population. Oral Oncol 47: 541-545, 2011.

134. Sokolosky ML, Stadelman KM, Chappell WH, Abrams SL, Martelli AM, Stivala F, Libra M, Nicoletti F, Drobot LB, Franklin RA, et al: Involvement of Akt-1 and mTOR in sensitivity of breast cancer to targeted therapy. Oncotarget 2: 538-550, 2011

135. McCubrey JA, Abrams SL, Ligresti G, Misaghian N, Wong EW, Steelman LS, Bäsecke J, Troppmair J, Libra M, Nicoletti F, et al: Involvement of p53 and Raf/MEK/ERK pathways in hematopoietic drug resistance. Leukemia 22: 2080-2090, 2008.

136. McCubrey JA, Steelman LS, Franklin RA, Abrams SL, Chappell WH, Wong EW, Lehmann BD, Terrian DM, Basecke J, Stivala F, et al: Targeting the RAF/MEK/ERK, PI3K/AKT and p53 pathways in hematopoietic drug resistance. Adv Enzyme Regul 47: 64-103, 2007.

137. Gangemi S, Miozzi E, Teodoro M, Briguglio G, De Luca A, Alibrando C, Polito I and Libra M: Occupational exposure to pesticides as a possible risk factor for the development of chronic diseases in humans (Review). Mol Med Rep (In press). 